\title{
PENGEMBANGAN BUKU AJAR BERBASIS SCIENTIFIC APPROACH PADA MATA PELAJARAN PRAKTIKUM AKUNTANSI LEMBAGA/INSTANSI PEMERINTAH
}

\author{
Oleh : Devi Nabilajaya ${ }^{1}$, Agung Listiadi ${ }^{2}$ \\ devinabilaj4@gmail.com ${ }^{1}$, agunglistiadi@unesa.ac.id ${ }^{2}$ \\ (Program Studi Pendidikan Akuntansi, FE Universitas Negeri Surabaya)
}

\begin{abstract}
Abstrak-Penelitian pengembangan ini bertujuan untuk menghasilkan buku ajar melalui pendekatan saintifik pada mata pelajaran praktikum akuntansi lembaga/instansi pemerintah kelas XI di SMK Negeri 10 Surabaya. Selain itu, penelitian ini juga bertujuan untuk menganalisis kelayakan dan respon peserta didik pada buku ajar berbasis scientific approach yang dikembangkan. Motode penelitian yaitu pengembangan. Adapun model pengembangan yang digunakan adalah model 4D dari Thiagarajan yang meliputi tahap define, design, dan develop. Hasil pengembangan menunjukkan bahwa hasil validasi para ahli pada buku ajar menjukkan rerata sebesar 94,84\% dan respon peserta didik sebesar 95,12\%. Dapat disimpulkan bahwa buku ajar berbasis scientific approach sangat layak digunakan dalam pembelajaran.
\end{abstract}

Kata Kunci: Buku Ajar, Scientific Approach, Praktikum Akuntansi Lembaga/Instansi Pemerintah.

\begin{abstract}
This development research aims to produce textbook by approaching rendering on the subjects of institutions accounting practices/goverment in the class XI in SMK Negeri 10 Surabaya addition, this research aims to know analyzing and student response against institutions textbook scientific approach. As for development models that used 4D model from Thiagarajan which includes the phase of define, design, and develop. The results of the this study show the average results shows textbook feasibility of $94,84 \%$ and student respons of students was 95,12\%. Concluded, produces textbook based on scientific approach institutions accounting practices/goverment is declared very valid so it is frasible to used in learning.
\end{abstract}

Keywords: Textbook, Scientific Approach, Institutions Accounting Practies /Government.

\section{PENDAHULUAN}

Abad milenium ke-3 yang berlangsung pada 2001-2100 atau lebih dikenal dengan abad 21 adalah masa berlangsungnya fenomena kapital yang berasal dari masyarakat industri mencapai masyarakat yang kaya pengetahuan (Soh,Arsyad \& Osman, 2010). Menurut Daryanto dan Syaiful Karim (2017) abad 21 memerlukan beberapa keterampilan dasar intelektual emosional, sosial, serta religius dalam berpengetahuan seperti keterampilan berpikir kritis 
dalam memecahkan masalah, berkomunikasi, penguasaan teknologi informasi, kreatif, kemampuan bekerjasama, metakognitif, dan menjadi pembelajar sepanjang hayat.

Abad 21 tidak terlepas dari adanya perubahan suatu pendidikan yang memotivasi peserta didik agar mengantongi basis pengetahuan dan pemahaman yang mendalam untuk menjadi pembelajar life-long learner. Dengan demikian, penting adanya perhitungan sistem pendidikan melalui ranah aspek pendidikan abad 21 di berbagai belahan dunia. Sejalan dengan perihal tersebut, Kemendikbud merumuskan bahwa paradigma pembelajaran abad 21 di Indonesia menekankan pada kemampuan peserta didik dalam mencari tahu dari berbagai sumber, merumuskan permasalahan, berpikir analitis dan bekerjasama serta berkolaborasi dalam menyelesaikan suatu masalah yang mereka temukan (Litbang Kemendikbud,2013).

Dewasa ini, pendidikan Indonesia menggunakan kurikulum 2013 yang dianggap sesuai dengan paradigma pembelajaran abad 21 di Indonesia karena didalanya termuat beberapa aspek berimbang seperti kompetensi sikap, keterampilan, serta pengetahuan. Menurut Sari, V, F., Mayar, A., Fefri, I,I., dan Mia, A,S (2019) menyatakan bahwa penerapan kurikulum 2013 dalam pembelajaran abad 21 mampu menghasilkan penerus bangsa yang terampil dalam menghasilkan karya (produktif), menghasilkan kreasi baru (inovatif), menghasilkan perubahan sikap dan nilai yang baik (afektif) melalui pelaksanaan pembelajaran dalam lingkup pendidikan berorientasi pada kemampuan pengetahuan kritis dan kreatif.

Menurut SK Dirjen Dikdasmen No. 130/D/Kep/KR/2017 Tentang struktur kurikulum SMK dalam kurikulum 2013 revisi 2017, memaparkan adanya beberapa inovasi dalam struktur pengaplikasiannya. Salah satu inovasi struktur kurikulum 2013 revisi 2017 adalah penambahan kompetensi keahlian yang tersaji dalam jurusan akuntansi dan lembaga keuangan. Inovasi ini terjadi dalam bentuk penambahan mata pelajaran praktikum akuntansi lembaga/instansi pemerintah baik pada kelas XI ataupun kelas XII.

Ketersediaan bahan ajar dalam pembelajaran mata pelajaran praktikum akuntansi lembaga/instansi pemerintah mutlak dilakukan dengan adanya dukungan bahan ajar didalamnya. Bahan ajar adalah kumpulan bahan yang diatur sedemikian rupa untuk membantu pengguna dalam pembelajaran dikelas. Bahan ajar yang sering difungsikan oleh guru dalam pembelajaran adalah bahan ajar cetak seperti lembar kerja peserta didik, modul, handout, dan buku ajar. 
Menurut Nasution dalam Trianto (2015) bahan ajar cetak yang kian intens difungsikan guru dalam pembelajaran daripada bahan lain adalah buku ajar. Buku ajar merupakan buku dasar yang di aplikasikan dalam proses pembelajaran berkualitas melalui peningkatan kemampuan pengetahuan ilmiah dan teknis yang dirangkai berdasarkan standar nasional untuk pendidikan terkait. Buku ajar sebaiknya diorganisasikan melalui dasar dalam pendekatan pembelajaran tertentu sehingga memiliki pijakan dasar dan terarah (Syamsi, K., Esti, S.,Setyawan, P, 2013).

Salah satu upaya yang dapat ditempuh dalam meningkatkan kualitas pembelajaran adalah dengan melakukan inovasi model pembelajaran melalui pendekatan saintifik. Pendekatan saintifik atau Scientific approach adalah penghampiran dalam prosedur pembelajaran dengan penggunaan dasar kaidah ilmiah dalam kegiatan belajar mengajar, pendekatan ini diharapkan mampu menciptakan peserta didik yang berpikir kritis, analitis, memenuhi syariat ilmu pengetahuan, dan sesuai dengan keadaan yang ada (Kemendikbud, 2014). Sedangkan menurut Daryanto (2014) pembelajaran melalui pendekatan saintifik memerlukan prosedur keterampilan secara berkesinambungan melalui kegiatan mengamati, yang disusul dengan kegiatan menanya, lalu mengumpulkan informasi, selanjutnya menalar informasi, serta mengkomunikasikan hasil (5M).

Menurut tanya jawab yang dilakukan dengan guru praktikum akuntansi lembaga/instansi pemerintah di SMK Negeri 10 Surabaya, peneliti mendapat beberapa informasi, didalamnya, (1) mata pelajaran terkait relatif baru, sebab pembelajaran pada mata pelajaran ini aktual terealisasi selama 2 (dua) tahun dan sumber belajar yang digunakan terbatas; (2) bahan ajar berupa buku pelajaran telah tersedia namun tidak sesuai dengan kurikulum yang berlaku dengan pendekatan saintifik didalamnya; dan (3) pihak pengadaan bahan ajar kesulitan untuk membuat bahan ajar yang memenuhi persyaratan khusus dalam kurikulum 2013 revisi karena terbatasnya informasi.

Melihat permasalahan diatas maka dapat ditarik kesimpulan bahwa kurikulum 2013 revisi 2017 belum terealisasi secara maksimal, sehingga bahan ajar berbentuk buku ajar yang disinkronkan dengan kurikulum 2013 revisi 2017 perlu dikembangkan. Dalam pengembangan buku ajar berbasis saintifik pada mata pelajaran praktikum akuntansi lembaga/pemerintah kelas XI memuat kompetensi dasar 3.4, 3.5, dan 3.6 dikarenakan belum adanya buku ajar yang menekankan materi secara berkesinambungan dengan 
potensi, kebutuhan peserta didik, masyarakat, dan lingkungan. Latar belakang lain adanya pengembangan buku ajar ini adalah kompetensi dasar tersebut memuat dasar pencatatan akuntansi keuangan desa/kelurahan yang perlu diberikan penjelasan secara tepat dan terorganiasi dengan baik.

Buku ajar dilengkapi dengan gambar, ilustrasi, peta konsep, glosarium, fitur FYI (For Your Information), quiz corner serta latihan soal pilihan beganda dan uraian berbasis higher order thinking skills.

Keberhasilan penggunaan buku ajar berbasis pendekatan saintifik dapat terlihat dalam penelitian "Pengembangan Buku Ajar Akuntansi Kas Berbasis Scientific Approach pada Mata Pelajaran Akuntansi Keuangan Kelas XI di SMK Negeri Se-Surabaya" memperoleh kualifikasi kelayakan $83,5 \%$ dan tanggapan peserta didik $88,7 \%$ sehingga layak digunakan (Octaviana, 2015). Penelitian lain juga dilakukan terhadap buku ajar berjudul "Pengembangan Buku Ajar Berbasis Scientific Approach pada Mata Pelajaran Praktikum Akuntansi Lembaga/Instansi Pemerintah di Kelas XI AKL SMK Negeri 2 Tuban" kualifikasi kelayakan 91,47\% dan tanggapan peserta didik $88,92 \%$ sehingga layak digunakan (Fitri, 2019). Sejalan dengan penelitian yang berjudul "Pengembangan Bahan Ajar
Berbasis Saintifik Sebagai Suplemen Mata Pelajaran Praktikum Akuntansi Lembaga/Instansi Pemerintah Kelas XI Materi Akuntansi Desa" kualifikasi kelayakan 87,66\% dan tanggapan peserta didik 90\% sehingga layak digunakan (Masum \& Rochmawati, 2019).

Dari paparan di atas, peneliti bertujuan melantaskan penelitian berjudul "Pengembangan Buku Ajar Berbasis Scientific Approach pada Mata Pelajaran Praktikum Akuntansi Lembaga/ Instansi Pemerintah kelas XI di SMK Negeri 10 Surabaya".

\section{METODE PENELITIAN}

Penelitian ini menggunakan model 4D yang mengacu pada Teori Thiagarajan dengan menempuh 3 (tiga) tahap dari 4 (empat) tahapan yakni tahap pendefinisian(define), tahap perancangan (design), pengembangan (develop), tanpa melalui tahap penyebaran (dessiminate) karena keterbatasan peneliti. Dasar yang digunakan peneliti dalam penggunaan model 4D karena model pengembangan 4D dianggap mampu menjadikan pangkal pengetahuan dan langkah pengembangan dalam mengembangkan bahan ajar dalam pembelajaran (Rochmad,2012).

Subjek uji coba dalam pengembangan buku ajar ini terdiri dari 3 (tiga) ahli yang bertindak selaku ahli materi dengan memberikan masukan dan penilaian 
kelayakan isi dan penyajian, ahli bahasa dengan memberikan masukan dan penilaian kelayakan penggunaan bahasa dan ahli kegrafikan dengan memberikan masukan dan penilaian kelayakan kegrafikan yang digunakan dalam penyusunan buku ajar praktikum akuntansi lembaga/instansi pemerintah. Peserta didik yang diambil dalam uji coba terbatas sejumlah 20 peserta didik jurusan AKL kelas XI di SMK Negeri 10 Surabaya dengan kriteria telah menerima materi yang diperkenalkan dalam buku ajar.

Data yang digunakan, meliputi data kualitatif dan data kuantitatif. Menurut Riduwan (2018) data kualitatif adalah akumulasi kategoris yang dapat dikomunikasikan melalui kata verbal. Sedangkan, data kuantitatif menurut Riduwan (2018) adalah akumulasi yang dapat dihitung dalam gambaran digital. Adapun data kualitatif yang digunakan adalah data yang berpangkal pada hasil telaah para ahli guna memperoleh informasi yang dijadikan referensi dalam perbaikan produk. Sementara untuk data kuantitatif berupa validasi para ahli dan data hasil tanggapan peserta didik pada buku ajar dengan acuan penskoran secara berturut-turut menggunakan Skala Likert dan Skala Guttman yang diolah dalam bentuk prosentase.

Instrumen dalam akumulasi data yang digunakan berupa kuesioner terbuka dan tertutup. Kuesioner terbuka berwujud lembar telaah para ahli yang berisi saran dan pentunjuk terhadap komponen kelayakan isi, bahasa, serta grafik dalam penyajian produk buku ajar yang digunakan. Kuesioner tertututup berwujud lembar validasi para ahli serta angket tanggapan peserta didik guna memperoleh penilaian para ahli serta tanggapan dari pesera didik terkait kelayakan buku ajar yang dikembangkan.

Analisis deskriptif diperoleh melalui lembar telaah yang diisi oleh para ahli guna memperbaiki buku ajar dan menyempurnakan bahan ajar melalui kriteria isi dan penyajian, bahasa serta kegrafikan buku. Lembar validasi yang terisi oleh para ahli selanjutnya akan dianalisis melalui data deskriptif kuantitatif berbentuk prosentase.

Prosentase validasi diperoleh dari penskoran melalui penilaian lembar validasi dengan penggunaan Skala Likert dengan ketentuan nilai sebagai berikut: (1) nilai/skor "5" masuk dalam kriteria sangat baik ; (2) nilai/skor "4" baik; (3) nilai/skor "3" sedang; (4) nilai/skor "2" tidak baik" dan (5) nilai/skor "1" sangat tidak baik. Dan untuk angket tanggapan peserta didik perolehan prosentase didapat melalui pengisian angket dengan penggunaan Skala Guttman melalui jawaban "Ya" bernilai 1 dan jawaban "Tidak" bernilai 0 .

Melalui analisis lembar telaah yang terisi oleh para ahli, penggunaan Skala Likert dapat digunakan untuk menjelaskan kriteria 
interprestasi yang disajikan melalui kesimpulan kualifikasi buku ajar: tabel berikut ini untuk menarik

Tabel 1. Ketentuan Interprestasi Validasi Ahli

\begin{tabular}{|c|c|}
\hline Prosentase & Kriteria Interprestasi \\
\hline $81 \%-100 \%$ & Sangat Layak \\
\hline $61 \%-80 \%$ & Cukup Layak \\
\hline $41 \%-60 \%$ & Layak \\
\hline $21 \%-40 \%$ & Tidak Layak \\
\hline $0 \%-20 \%$ & Sangat Tidak Layak \\
\hline
\end{tabular}

Sumber: Riduwan, 2018

Berdasarkan tabel diatas, dapat disimpulkan bahwa jika prosentase $\geq$ $61 \%$ diperoleh, buku teks yang dikembangkan dianggap layak untuk digunakan.
Skala Guttman diperlukan dalam menganalisis akumulasi data angket peserta didik dan menarik kesimpulan melalui kriteria interprestasi skor melalui tabel berikut:

Tabel 2. Ketentuan Interprestasi Angket Peserta Didik

\begin{tabular}{|c|c|}
\hline Prosentase & Kriteria Interprestasi \\
\hline $81 \%-100 \%$ & Sangat Memahami \\
\hline $61 \%-80 \%$ & Memahami \\
\hline $41 \%-60 \%$ & Cukup Memahami \\
\hline $21 \%-40 \%$ & Kurang Memahami \\
\hline $0 \%-20 \%$ & Sangat Kurang Memahami \\
\hline
\end{tabular}

Sumber: Riduwan, 2018

Berdasarkan tabel interprestasi tanggapan peserta didik atas buku ajar dinyatakan layak apabila memperoleh prosentase $\geq 61 \%$.

\section{HASIL DAN PEMBAHASAN}

\section{Proses Pengembangan Buku Ajar} Berbasis Scientific Approach

Secara utuh proses pengembangan buku ajar menempuh 3 (tiga) tahap dari 4 (empat) tahapan pengembangan yakni define, design, dan develop tanpa dessiminate karena keterbatasan peneliti. Pertama tahap pendefinisian (define) yang meliputi 4 (empat) cara didalamnya yaitu analisis awal akhir, peserta didik, tugas, dan perincian arah pembelajaran. Analisis awal akhir dilangsungkan lewat studi pendahuluan yang membuahkan beberapa analisa yaitu kurikulum 2013 menuntut peserta didik dalam kegiatan pembelajaran saintifik 
melalui 5M (mengamati, yang disusul dengan kegiatan menanya, lalu mengumpulkan informasi, selanjutnya menalar informasi atau mencoba,serta mengkomunikasikan hasil) yang mampu mengembangkan pola berpikir analitis, kurikulum 2013 revisi 2017 yang diterapkan pada SMK/MAK mengakibatkan adanya penambahan mata pelajaran yang salah satunya adalah mata pelajaran praktikum akuntansi lembaga/instansi pemerintah. Dalam aplikasi, guru belum dapat menemukan bahan yang cocok dengan KI dan KD untuk pembelajaran, hal ini memunculkan perilaku peserta didik yang merasa kesulitan dalam mempelajari materi, isi. Penyajian materi yang digunakan belum sesuai dengan kurikulum, serta buku ajar yang digunakan belum menampilkan soal yang mampu mengasah mampu mengasah keahlian berpikir tingkat lanjut peserta didik. Menurut analisis ini, dapat diketahui bahwa kondisi lapangan perlu melakukan adaptasi secara berkala melalui bahan ajar dan kurikulum pembelajaran.

Analisis peserta didik menunjukkan bahwa pertama, peserta didik memiliki kisaran usia antara 1617 tahun, kisaran usia ini menurut teori pengembangan kognitif dari Piaget, peserta didik masuk ke dalam ranah operasional formal (Nursalim,dkk 2019) dimana peserta didik dianggap mampu menganalisis masalah dan memecahkan hipotesis secara mandiri dengan baik, kedua peserta didik memiliki karakteristik pasif dalam pembelajaran berlangsung dan kurang mampu memcahkan masalah dan membangun konsep mandiri terlebih pada soal higher order thinking skills, ketiga peserta didik lebih condong menyukai bahan ajar cetak dan dapat dimiliki secara mandiri, dan keempat peserta didik mengunginkan bahan ajar yang mampu mendorong atau memotivasi mereka untuk giat belajar. Menurut analisis peserta didik, diketahui bahwa bahan ajar cetak diperlukan sesuai tingkatan usia, kemampuan berpikir, fleksibel dan mampu mendorong peserta didik dalam belajar.

Analisis tugas, arah tahap ini adalah mengenali sejauh mana peserta didik akan memperoleh keahlian yang akan dikuasai oleh peserta didik melalui pendekatan saintifik. Keahlian ini juga akan disinkronkan dengan kompetensi yang ada pada mata pelajaran tekait serta kurikulum 2013 revisi 2017. Tugas yang wajib diselesaikan peserta didik dalam studi mereka adalah peserta didik melakukan kegiatan mengamati dalam bentuk membaca uraian kasus ataupun menelaah contoh ilustrasi yang berkesinambungan dengan materi yang termuat dalam buku ajar, menuliskan pendapat atau analisa sebagai bentuk pertanggungjawaban dari kegiatan mengamati, mempelajari materi yang termuat 
dalam buku ajar diimbangi dengan mengumpulkan informasi pendukung dari sumber lain yang relevan, mengerjakan soal baik secara mandiri ataupun kelompok , melakukan kegiatan presentasi, merangkum serta diskusi bersama, pada penghujung kegiatan belajar, peserta didik diarahkan agar menyelesaikan tugas secara mandiri untuk menaksir wawasan peserta didik, dan pada akhir setiap bab, peserta didik diarahkan untuk mengerjakan soal evaluasi.

Analisa konsep, analisis ini didasarkan pada penentuan materi pokok yang sesuai dengan kurikulum yang dikembangakan melalui buku ajar. Konsep ini disusun melalui pijakan materi pokok yang akan dijadikan dasar perincian tujuan pembelajaran. Adapun kompetensi dasar dalam pengembangan ini adalah KD 3.4, 3.5, dan 3.6. Analisis konsep kemudian ditulis dalam bentuk peta konsep pada setiap awal bab dalam buku ajar.

Tahap perancangan (design), prosedur ini diperlukan untuk membuat pola buku ajar yang dikembangkan melalui format dan desain awal buku ajar yang nantinya akan membuahkan hasil draft I. Penyusunan format buku ajar termasuk pendahuluan, bagian isi, serta bagian penutup. Struktur buku ajar yang dikembangkan disetarkan dengan BSNP dan Direktorat Pembinaan SMA, dan dimodifikasi dengan pendekatan saintifik pada isi buku ajar serta beberapa hal lain yang dikembangkan oleh peneliti (Bridges\&Hallinger, 2015). Langkah selanjutnya ditempuh dengan tahap perancangan dari format buku ajar, melalui kegiatan pengaturan warna atau ilustrasi yang ditampilkan pada buku ajar, mengendalikan tata letak buku, hingga memilih menyeleksi kekontrasan warna yang akan digunakan. Adapun salah satu proses dalam desain awal buku ajar adalah penetapan format cover buku ajar yang memuat unsur-unsur didalamnya seperti penulis buku, logo instansi besertalogo kurikulum 2013, judul buku ajar, pemilihan ilustrasi yang mampu mewakili isi dari buku ajar serta sasaran pengguna buku. Perancangan cover buku ajar dibuat semenarik mungkin untuk meransang minat atau motivasi peserta didik dalam membaca isi dari buku ajar. Warna dominan yang digunakan untuk cover adalah putih. Warna putih dipilih karena identik atau mampu menimbulkan kesan modernitas dan juga pengetahuan dalam bidang akuntansi pada khususnya. Secara psikologi, warna putih mampu melambangkan unsur kebebasan dan keterbukaan dalam segala bidang pada umumnya didalamnya khususnya pada bidang pendidikan.

Pada tahap pengembangan (develop), produk berwujudu buku ajar yang sebelumnya dirancang oleh peneliti dan menghadirkan draft I selanjutnya akan dilakukan telaah 
oleh ahli materi, perbaikan, validasi atau verifikasi, serta uji coba terbatas. Telaah oleh para ahli terdiri atas pemberian komentar oleh ahli materi, bahasa serta grafik untuk memperoleh masukan beserta saran dalam rangka memperbaiki dan menyempurnakan buku ajar yang dikembangkan.Ahli materi menyarankan adanya beberapa perbaikan berupa penambahan soal evaluasi, kunci jawaban, dan perubahan tulisan sub judul tahap "menanya" menjadi menanya. Hal tersebut disarankan agar jumlah soal evaluasi yang ada dibuku ajar sama rata yakni terdiri dari 15 soal dengan komposisi 10 pilihan berganda dan 5 uraian, penambahan kunci jawaban disesuaikan dengan adanya penambahan soal evaluasi, dan penulisan subjudul pada tahap "menanya" menjadi "menanya?" dilakukan agar sesuai dengan kalimat ejaan bahasa indonesia. Ahli bahasa menyarankan adanya beberapa perbaikan berupa penambahan informasi tentang produk pada bagian cover buku, penambahan kalimat pada kata pengantar yang mampu menekankan informasi keunggulan produk, dan memperbaiki sapaan dalam produk menjadi sapaan yang lebih dekat dengan peserta didik. Ahli grafis menyarankan adanya perubahan terhadap gambar pada ilustrasi cover depan dan belakang buku yang mampu memberikan gambaran umum mengenai isi produk, perubahan terhadap penulisan KI dan KD yang terpisah menjadi kesatuan utuh, serta perubahan untuk menghindari ruang kosong pada buku ajar.

Hasil telaah para ahli akan dijadikan sebagai dasar untuk meningkatkan buku ajar. Setelah melaksanakan perbaikan langkah selanjutnya adalah meminta para ahli untuk menilai kelayakan buku ajar. Bentuk penilaian yang digunakan adalah penilaian dengan menggunakan lembar validasi yang disediakan berbentuk angket tertutup yang memiliki kisi-kisi yang disesuaikan dengan kriteria BSNP yang dapat menjadi acuan untuk mengembangkan buku ajar sesuai dengan standar nasional. Selanjutnya hasil penilaian atau validasi dianalisis menggunakan prosentase yang mampu diinterprestasikan. Setelah tahap tersebut selesai, dengan bantuan guru mata pelajaran terkait buku ajar yang dikembangkan akan diujicobakan secara terbatas pada 20 peserta didik yang dipilih secara random dengan merujuk pada pendapat Sadiman dalam Putri (2019) bahwa ujicoba dalam peneliain pengembangan mampu diujicobakan pada 20 peserta didik secara random yang dapat mempresentasikan populasi dalam penelitian, karena jika dalam penelitian mengambil populasi kurang dari 10 maka data yang diperoleh minim dalam menggunakan populasi targer, dan sebaliknya ketika penelitian menggunakan uji coba dengan 
populasi melebihi 20 peserta didik maka daya yang diperoleh kurang produktif digunakan dalam kelompok kecil.

\section{Kelayakan Buku Ajar Mata Berbasis Scientific Approach}

Kelayakan buku ajar dapat dilihat dari hasil validasi para ahli. Menururt BSNP (2014), kriteria dalam buku ajar yang dinilai untuk mengetahui kelayakan bahan ajar baik berupa cetak ataupun elekronik dapat ditempuh dengan penilaian komponen kelayakan isi dan penyajian, kelayakan bahasa, dan kesesuaian grafik. Penilaian yang dilakukan oleh para peneliti menggunakan Skala Likert.

Hasil validasi dalam komposisi isi dan penyajian materi diporoleh prosentase sebesar 93,74\%. Menurut Riduwan (2018) jika buku ajar memenuhi prosentase sebesar $\geq 61 \%$ maka dikatakan layak. Dengan prosentase sebesar 93,74\% komponen isi "Sangat Layak". Hal ini didapat karena perolehan penilaian melalui indeks kelayakan dari materi dan penyajian buku ajar yang dikembangkan sudah sesuai.

Dari aspek isi secara aktual, buku ajar memadahi dimensi kurikulum 2013 revisi 2017 melalui pengetahuan dan keterampilan yang tersaji secara metodis yang dikrusialkan bagi peserta didik sebagai pembaca (Hamdani,2016). Sementara itu, aspek penyajian yang dikembangkan dalam buku ajar mampu mengutarakan representatif yang termuat didalamnya. Dalam pengembangannya buku ajar menggunakan pendekatan saintifik dengan kegiatan $5 \mathrm{M}$ pada $\mathrm{KD} 3.4$, 3.5, dan 3.6 dikarenakan KD tersebut adalah KD dasar dari pencatatan akuntansi keuangan desa/kelurahan yang perlu diberikan penjelesan secara tepat

Buku ajar dilengkapi dengan beberapa fitur yaitu fitur FYI (For Your Information) sebagai daya ekspansi pengetahuan peserta didik tentang praktikum akuntansi lembaga/instansi pemerintah terbaru, quiz corner sebagai daya takar pengetahuan umum. Penyertaan latihan soal pilihan beganda dan uraian berbasis higher order thinking skill pada buku ajar diharapkan menjadil pola berpikir baru peserta didik dalam pengidentifikasian dan penyelesaian masalah melalui pendekatan non-spontan (Nugroho, 2018).

Kelayakan bahasa mencapai prosentase 98,57\%. Menurut Riduwan (2018) jika standar kelayakan buku ajar mencapai $\geq$ $61 \%$, buku ajar dikatakan layak. Dengan prosentase sebesar 98,57\% komponen kebahasaan "Sangat Layak". Hal ini dikarenakan perolehan penilaian melalui indikator kelayakan bahasa yang dikembangkan pada buku ajar sudah sesuai.

Kelayakan grafik diperoleh prosentase sebesar 95,83\%. Menurut 
Riduwan (2018) jika standar kelayakan buku ajar mencapai $\geq$ $61 \%$, buku ajar dikatakan layak. Dengan prosentase sebesar 95,83\% komponen kegrafikan "Sangat Layak". Hal ini dikarenakan perolehan penilaian melalui indikator kelayakan kegrafikan yang tertuang dan dikembangkan pada buku ajar sudah sesuai. Berdasarkan penialaian validasi oleh para ahli diperoleh rekapitulasi :

Tabel 3. Rekapitulasi Hasil Validasi Ahli

\begin{tabular}{|c|l|c|c|}
\hline No & \multicolumn{1}{|c|}{ Aspek } & Prosentase & Kriteria Interprestasi \\
\hline 1 & Kelayakan isi & $93,74 \%$ & Sangat Layak \\
\hline 2 & $\begin{array}{l}\text { Kelayakan } \\
\text { penyajian }\end{array}$ & $91,25 \%$ & Sangat Layak \\
\hline 3 & $\begin{array}{l}\text { Kelayakan } \\
\text { bahasa }\end{array}$ & $98,57 \%$ & Sangat Layak \\
\hline 4 & $\begin{array}{l}\text { Kelayakan } \\
\text { kegrafikan }\end{array}$ & $94,84 \%$ & Sangat Layak \\
\hline \multicolumn{2}{|c|}{$\begin{array}{l}\text { Rata-Rata } \\
\text { Keseluruhan }\end{array}$} & $\mathbf{9 4 , 8 4 \%}$ & Sangat Layak \\
\hline
\end{tabular}

Sumber: Diolah oleh peneliti, 2020

Hasil validasi keseluruhan buku ajar yang dikembangkan oleh para ahli rerata sebesar $94,84 \%$. Menurut Riduwan (2018) jika standar kelayakan buku ajar mencapai $\geq$ $61 \%$, Hal ini sejalan dengan Kemala dan Luqman Hakim (2019) yang mendapat hasil kelayakan buku ajar dengan rerata prosentase $85,65 \%$ dan dikriteriakan sebagai buku ajar dikatakan layak. Buku ajar yang dikembangkan mencapai prosentase 94,84\% dengan kriteria "Sangat Layak" ini mengemukakan asumsi bahwa pengembangan buku ajar sangat layak untuk digunakan sebagai bahan ajar.

\section{Respon Peserta Didik Terhadap Buku Ajar Berbasis Scientific Approach}

Kegiatan ujicoba produk secara terbatas pada peserta didik yang menjadi sasaran. Ujicoba diadakan untuk mendapatkan informasi dalam bentuk tanggapan peserta didik terhadap buku ajar yang dikembangkan. Pembagian lembar angket respon peserta didik dilakukan setelah uji coba buku ajar. Setelah, terisi dan terkumpul maka angket tersebut kemudian dihitung dan dikalkulasikan melalui prosentase dan di interprestasikan sesuai kriteria yang telah disajikan. Adapun komponen angket respon peserta didik diadaptasi dari Octaviana (2017) dan diolah peneliti. Secara 
keseluruhan komponen dalam angket ini memiliki unsur yang sama dengan komponen penilaian para ahli, namun untuk unsur kegrafikan dihilangkan dan dirubah menjadi unsur kesesuaian dalam kegiatan scientific approach (pendekatan saintifik).

Tabel 4. Rekapitulasi Angket Respon Peserta Didik

\begin{tabular}{|c|l|c|c|}
\hline No & \multicolumn{1}{|c|}{ Aspek } & Prosentase & Kriteria Interprestasi \\
\hline 1 & $\begin{array}{l}\text { Kelayakan isi dan } \\
\text { penyajian materi }\end{array}$ & $93,75 \%$ & Sangat Layak \\
\hline 2 & Kelayakan bahasa & $96 \%$ & Sangat Layak \\
\hline 3 & $\begin{array}{l}\text { Kesesuaian dengan } \\
\text { pendekatan saintifik }\end{array}$ & $95,62 \%$ & Sangat Layak \\
\hline \multicolumn{2}{|c|}{ Rata-Rata Keseluruhan } & $\mathbf{9 5 , 1 2 \%}$ & Sangat Layak \\
\hline
\end{tabular}

Sumber: Diolah oleh peneliti, 2020

Menurut rekapitulasi pengisian angket respon peserta didik yang disajikan, dapat dilihat bahwa prosentase rerata buku ajar adalah 95,12\%. Menurut Riduwan (2018) kriteria kelayakan untuk buku ajar dengan prosentase $\geq 61 \%$ dikriteriakan "Sangat Baik". Hal ini sejalan dengan Kemala dan Luqman Hakim (2019) yang mendapat hasil kuisioner dengan prosentase 93\% dan dikriteriakan sangat baik. Maka dapat dikonklusikan bahwa, pengembangan buku ajar dapat sangat memahami atau sangat baik digunakan dalam pembelajaran.

\section{KESIMPULAN}

Pengembangan yang dilaksanakan menghasilkan produk bentuk buku ajar berbasis scientific approach atau pendekatan ilmiah sebagai bahan ajar pembelajaran. Model pengembangan yang digunakan mengacu pada 4D teori
Thiagarajan yang meliputi define, design, develop tanpa tahap dessiminate karena keterbatasan peneliti.

Buku ajar berbasis scientific approach yang dikembangkan memiliki kriteria sangat layak digunakan sebagai bahan ajar dengan dasar penilaian para ahli baik materi, bahasa, dan kegrafikan.

Respon peserta didik terhadap buku ajar berbasis scientific approach yang telah dikembangkan adalah sangat memahami.

Bagi penelitian selanjutnya, melalui penelitian pengembangan diharapkan memiliki kemampuan lebih dalam mengembangkan buku pelajaraan yang lebih kreatif dan inovatif.

Untuk penelitian selanjutnya, dihimbau dapat mengembangkan buku pelajaran atau bahan ajar lain dengan berisi lebih dari tiga 
kompetensi dasar ataupun dalam satuan semester secara utuh.

Untuk penelitian lebih lanjut, diharapkan dapat mengembangkan buku ajar atau bahan ajar lain sampai pada tahap penyebaran (dessiminate).

\section{DAFTAR PUSTAKA}

Bridges \& Hallinger. Exploring The Us of Lesson Study with Six Canadian Middle School. Science Teachers, Volume 78 No.1(E): 363-373 (2015). Online (https://qspace.library .queensu.ca/.../1/Bridges_Terry J_201503 PHD.pdf). Diakses 20 Juni 2020 Pukul 08:00 WIB.

BSNP. (2014). Instrument Penilaian Buku Teks Pelajaran Tahun 2014. Jakarta: Badan Standar Nasional Pendidikan.

Daryanto. (2014). Pendekatan Pembelajaran Saintifik Kurikulum 2013. Yogyakarta: Penerbit Gava Media.

Daryanto dan Syaiful. (2017). Pembelajaran Abad 21. Yogyakarta: Penerbit Gava Media

Fitri. (2019). Pengembangan Buku Ajar Berbasis Scientific Approach Pada Mata Pelajaran Praktikum Akuntansi Lembaga/Instansi Pemerintah di Kelas XI AKL SMK Negeri 2 Tuban. Jurnal Pendidikan Akuntansi. Volume 3 No. 9 (2019) 108-116. Online(https://jurnalmahasiswa .unesa.ac.id/index.php/jpak/iss ue/view/1852). Diakses Senin 22 Juni 2020 Pukul 15:00 WIB.
Hamdani. (2016). Strategi Belajar Mengajar. Bandung: CV Pustaka Setia.

Kemala \& Luqman Hakim. Pengembangan Buku Ajar Layanan Lembaga Keuangan Syariah Berbasis Scientific Approach dengan Integrasi Teknologi QR Code. Jurnal Pendidikan Akuntansi. Volume 3 No. 2 (2019). 125-134 (https://journal. unesa.ac.id/index.php/jpeka/art icle/view/5320). Diakses 23 Juli 2020 Pukul 09:00 WIB.

Kemendikbud. (2014). Peraturan Menteri Pendidikan dan Kebudayaan 103.

Litbang Kemendikbud. (2013). Kurikulum 2013: Pergesaran Paradigma Belajar Abad 21. Jakarta:Kemendikbud.

Masum, Akhmad. \& Rochmawati. Pengembangan Bahan Ajar Berbasis Saintifik Sebagai Suplemen Mata Pelajaran Praktikum Akuntansi Lembaga/Instansi Pemerintah Kelas XI Materi Akuntansi Desa. Jurnak Pendidikan Akuntansi. Volume 7 No.3 (2019) 434-441. Online (https://jurnalmahasiswa.unesa. ac.id/index.php/jpak/article/vie w/30845). Diakses 22 Juli 2020 Pukul 13:30 WIB

Nursalim,dkk. (2013). Strategi dan Intervensi Konseling. Jakarta: Akademia Permata.

Nugroho, Arifin. (2018). Kemampuan Berpikir Tingkat Tinggi: Konsep, Pembelajaran, Penilaian, dan Soal-soal. Jakarta: PT Gramedia.

Octaviana. Pengembangan Buku Ajar Akuntansi Kas Berbasis 
Scientific Approach pada Mata Pelajaran Akuntansi Keuangan Kelas XI di SMK Negeri Se Surabaya. Jurnal Pendidikan Akuntansi. Volume 2 No. 4 (2015). $\quad 1-8 \quad$ Online (https://jurnalmahasiswa.unesa. ac.id/index.php/jpak/article/vie w/21343) Diakses 24 Juni 2020 Pukul 19:00 WIB.

Putri, E.W. Pengembangan Lembar Kegiatan Peserta Didik (LKPD) Berbasis Scientific Approach Pada Mata Pelajaran Tata Kelola Kepegawaian Semester Genap Kelas XI di SMK Negeri 2 Tuban. Jurnal Pendidikan Administrasi Perkantor-an. Volume 7 No. 2 (2019). 73-80. Online (https://jurnalmahasiswa. unesa.ac.id/index.php/JPAPUN ESA/article/view/28122).

Diakses 22 Juli 2020 Pukul 10:00 WIB

Riduwan. (2016). Skala Pengukuran Variabel-Variabel Penelitian. Bandung: Alfa Beta.

Rochmad. Desain Model Pengembangan Perangkat Pembelajaran. Jurnal Kreano, Volume 3 (2012) 59-71. Online(https://journal.unnes.ac. id/nju/index.php/kreano/article/ view/2613) Diakses 26 Juni 2020 Pukul 21:00 WIB.

Sani, Ridwan Abdullah. (2014). Pembelajaran Saintifik untuk Implementsai Kurikulum 2013. Jakarta: PT Bumi Aksara.

Sari, V, F., Mayar, A., Fefri, I,I., \& Mia, A,S. Pelatihan Penyusunan Jobsheet Mata Pelajaran Praktikum Akuntansi Lembaga/Instansi Pemerintah Bagi Tim MGMP Akuntansi
Provinsi Sumatera Barat. Jurnal Kuat, Volume 1 No.1 (2019) 15-19. Online (http://jurnal.pknstan .ac.id/index.php/KUAT/article/ view/457). Diakses Rabu 22 Juli 2020 Pukul 16:00 WIB.

Soh,T., Arsyad,N., \& Osman,K. The Relationship of $21^{\text {st }}$ Century Skills On Student Attitude And Perception Towards Physics. Procedia Social and Behavioral Sciences. Volume 7C No. 3 (2010). 546-554. Online

(https://pdf.sciencedirectassets. com/277811/1-s2.0-

$\underline{\mathrm{S} 1877042810 \mathrm{X} 0012 \mathrm{X} / 1 \text {-s2.0 }}$ S187704281002077X/main .pdf). Diakses Kamis 23 Juli 2020 Pukul 22:00 WIB.

Syamsi, K., Esti, S.,Setyawan, P. Pengembangan Model Buku Ajar Membaca Berdasarkan Pendekatan Proses Bagi Siswa SMP. Cakrawala Pendidikan. Volume No. 2 No. 35 (2013). Online (https://journal.uny.ac .id/index.php/cp/article/view/1 262). Diakses Kamis 23 Juli 2020 Pukul 22:30 WIB.

Trianto. (2015). Mendesain Model Pembelajaran Inovatif, Progresif, dan Kontekstual. Jakarta: Kencana. 